\title{
Therapy of Delta Hepatitis
}

\author{
Cihan Yurdaydin ${ }^{1,2}$ and Ramazan Idilman ${ }^{1}$ \\ ${ }^{1}$ Department of Gastroenterology, University of Ankara Medical School, Ankara 06100, Turkey \\ ${ }^{2}$ Hepatology Institute, University of Ankara, Ankara 06100, Turkey \\ Correspondence: cihan.yurdaydin@medicine.ankara.edu.tr
}

Delta hepatitis is the less frequently encountered but most severe form of viral hepatitis. Acute delta hepatitis, as a result of coinfection with hepatitis B and hepatitis delta, is rare, but may lead to fulminant hepatitis, and no therapy exists for this form. Chronic delta hepatitis $(\mathrm{CDH})$ mostly develops as a result of superinfection of a hepatitis B surface antigen (HBsAg) carrier with hepatitis delta virus (HDV). In general, HDV is the dominant virus. However, a dynamic shift of the dominant virus may occur with time in rare instances, and hepatitis $B$ virus (HBV) may become the dominant virus, at which time nucleos(t)ide analog therapy may be indicated. Otherwise, the only established management of $\mathrm{CDH}$ consists of conventional or pegylated interferon therapy, which has to be administered at doses used for hepatitis B for a duration of at least 1 year. Posttreatment week-24 virologic response is the most widely used surrogate marker of treatment efficacy, but it does not represent a sustained virologic response, and late relapse can occur. As an easy-to-use simple serological test, anti-HDVimmunoglobulin M (IgM) correlates with histological inflammatory activity and clinical long-term outcome; however, it is not as sensitive as HDV RNA in assessing treatment response. No evidence-based rules for treating $\mathrm{CDH}$ exist, and treatment duration needs to be individualized based on virologic response at end of treatment or end of follow-up. Effective treatment may decrease liver-related complications, such as decompensation or liver-related mortality. In patients with decompensated cirrhosis, interferons are contraindicated and liver transplantation has to be considered. Alternative treatment options are an urgent need in $\mathrm{CDH}$. New treatment strategies targeting different steps of the HDV life cycle, such as hepatocyte entry inhibitors or prenylation inhibitors, are emerging and provide hope for the future.

$\mathrm{D}^{\mathrm{e}}$ elta hepatitis is the most severe form of viral hepatitis affecting humans. This applies to both its acute and its chronic form. The causative agent, hepatitis D virus (HDV), discovered more than 35 years ago (Rizzetto et al. 1977), can lead to disease in humans only when it is present with the hepatitis B virus (HBV). As with other dual viral infections, therapy has to be tailored toward the dominant virus, which for the vast majority of cases is the HDV. In the rare instance in which the dominant virus changes (Boyd et al. 2010; Schaper et al. 2010), treating HBV may be considered (Yalçın et al. 2003). As with the other forms of chronic viral hepatitis, such as chronic hepatitis $\mathrm{B}(\mathrm{CHB})$ or chronic hepatitis $\mathrm{C}(\mathrm{CHC})$, the first effective treatment for chronic delta hepatitis $(\mathrm{CDH})$ was treatment with interferons. First attempts of treating delta hepatitis started in the 1980s with the use of conventional interferons (Farci et al. 1989;

Editors: Christoph Seeger and Stephen Locarnini

Additional Perspectives on Hepatitis B and Delta Viruses available at www.perspectivesinmedicine.org

Copyright (C) 2015 Cold Spring Harbor Laboratory Press; all rights reserved; doi: 10.1101/cshperspect.a021543

Cite this article as Cold Spring Harb Perspect Med 2015;5:a021543 
Rosina et al. 1989; Di Besceglie et al. 1990). Short-term $(2-24 \mathrm{wk})$ interferon treatment was associated in some patients with biochemical and virologic improvement, which, in most cases, reverted after treatment discontinuation, and the need for longer treatment duration became obvious. After a quarter of a century, treatment of CDH has not changed, except that use of conventional interferons has been replaced by pegylated interferons. Major breakthroughs witnessed in the treatment of $\mathrm{CHB}$ and $\mathrm{CHC}$, so far, did not occur in the management of $\mathrm{CDH}$. Three main arguments for the lack of progress in the management of $\mathrm{CDH}$ can be raised: (1) breakthroughs in treatment of $\mathrm{CHB}$ and $\mathrm{CHC}$ rely on efforts tailoring treatment to different steps of the life cycle of the hepatitis B and hepatitis C virus, respectively. Because HDV needs HBV for propagation, measures to control HBV infection should have theoretically been effective in treating $\mathrm{CDH}$. This did not occur, however, because the breakthrough in $\mathrm{HBV}$ treatment came with the development of nucleos(t)ide analogs (NAs), which revolutionized the management of $\mathrm{CHB}$. However, NAs target the HBV polymerase, a multifunctional protein essential for HBV viral replication (Fung et al. 2011) and have proven to be very effective in inhibiting this enzyme, resulting in the cessation of necroinflammation, progression of liver disease, and positively affecting the natural history of $\mathrm{CHB}$ disease (Lok and McMahon 2009; EASL Clinical Practice Guidelines 2012). This has deferred basic and clinical research in targeting other steps of the HBV life cycle, which could have been of benefit for treating HDV as well. On the other hand, the beneficial effect of NAs in CHB monoinfection had no impact on $\mathrm{CDH}$. This was not unexpected because the only HBV function required for HDV propagation is hepatitis B surface antigen (HBsAG) synthesis, and NAs do not target HBsAg synthesis. (2) In contrast to HBV and HCV infection, direct inhibition of HDV replication is not possible. HDV replicates through a double-rolling circling model and also makes use of a polymerase, the cellular RNA polymerase II, with contributory functions of RNA polymerase I and III (GrecoStewart et al. 2009; Taylor 2012), all of which are host polymerases and should, therefore, not be targeted because of toxicity. (3) HDV is becoming an infrequent problem despite hot spots of hyperendemic disease mainly affecting areas of the world with low socioeconomic status (Wedemeyer and Manns 2010; Hughes et al. 2011). The low financial reward is unfortunately a likely explanation for the lack of interest by major pharmaceutical companies in developing drugs for $\mathrm{CDH}$, and the challenge of drug development relies now more on academic institutions. However, management of $\mathrm{CDH}$ is likely to enter a new area very soon because the first human trials on the use of treatment strategies targeting different steps of the HDV life cycle are ongoing and results are expected to be disclosed soon.

\section{TREATMENT OF ACUTE DELTA HEPATITIS}

Acute delta hepatitis $(\mathrm{ADH})$ resembles a typical self-limited hepatitis that is clinically and histologically indistinguishable from hepatitis B or other types of viral hepatitis. It may, however, lead to a biphasic type of hepatitis, possibly related to sequential expression of the two viruses that have been observed both in early chimpanzee studies (Rizzetto et al. 1980) and prospectively in injecting drug users (Caredda et al. 1985). The acute hepatitis can clinically range from mild hepatitis to fulminant hepatitis leading to death. Early studies both from the United States and Europe had clearly shown that coinfection of HBV HDV more often leads to severe or fulminant hepatitis compared to patients monoinfected with HBV (Smedile et al. 1982; Govindarajan et al. 1984; Caredda et al. 1987). However, a more recent study from Spain (Buti et al. 2011) reported the development of fulminant hepatitis attributable to HBV HDV in only two (1.7\%) out of 115 patients, and may suggest that, with the slower turnover of HDV in the community, acute fulminant HDV may also be much less frequently encountered. This is good news, as no therapy of proven efficacy exists for the treatment of $\mathrm{ADH}$. In this context, trisodium phosphonoformate (foscarnet) and interferon (IFN) $-\alpha$ have been tested in the past as possible treatment regimens in $\mathrm{ADH}$. Three patients with fulminant hepatitis $\mathrm{D}$ were given 
foscarnet, an inhibitor of HBV replication, and each of them recovered (Niro et al. 2005b). However, in vitro data indicate that foscarnet actually enhances HDV replication; thus, its clinical success may have been a fortuitous effect (Niro et al. 2005b). Foscarnet was not further tested; its poor oral bioavailability and nephrotoxicity have been discouraging (Wagstaff and Bryson 1994; Niro et al. 2005b). IFN- $\alpha$ was associated with dismal results in patients with fulminant hepatitis D (Sanches-Tapias et al. 1987).

\section{TREATMENT OF CHRONIC DELTA HEPATITIS}

\section{Treatment with Interferons}

The only evidence-based effective therapy for $\mathrm{CDH}$ is treatment with interferons. Throughout the years, many drugs have been tested for $\mathrm{CDH}$, but none of them proved to be effective. The first attempts date back to the 1980s when immunosuppressive agents, such as prednisone and azathioprine, and immunostimulants, such as levamisole, were tested at a time when there was more or less only indirect evidence of $\mathrm{CDH}$ being an immune-mediated disease (Actis et al. 1987). None of these three agents proved to be effective (Arrigoni et al. 1983; Rizzetto et al. 1983). Although not as vigorously investigated as $\mathrm{CHB}$ or $\mathrm{CHC}$, there is now accumulating evidence that $\mathrm{CDH}$ is essentially an immunemediated disease (Grabowski and Wedemeyer 2010; Grabowski et al. 2011; Karatayli et al. 2014; Lunemann et al. 2014). However, there may be exceptions to this. Genotype-3 HDV has been reported to lead to a particularly severe form of delta hepatitis, whereas histologic findings are not reminiscent of an immune-mediated liver injury, and a cytopathic role for genotype 3 has been attributed (Casey et al. 1996).

The first studies with interferons were performed in the late 1980s. Several studies in the late 1980s and 1990s suggested that treatment duration should probably not be shorter than $1 \mathrm{yr}$, and that IFN- $\alpha-2 \mathrm{a}$ or IFN- $\alpha-2 \mathrm{~b}$ should be given at a dose of 9-10 million units thrice weekly (Rizzetto 2009; Yurdaydin et al. 2010). A list of controlled clinical trials (Rosina et al. 1991;
Farci et al. 1994; Madejon et al. 1994; Gaudin et al. 1995; Günşar et al. 2005; Canbakan et al. 2006; Yurdaydin et al. 2008) on the use of IFN- $\alpha$ $2 \mathrm{a}$ or IFN- $\alpha-2 \mathrm{~b}$ for a duration of $1 \mathrm{yr}$ is provided in Table 1. With the advent of pegylated interferon, more recent studies have made use of this type of therapy (Castelnau et al. 2006; Erhardt et al. 2006; Niro et al. 2006; Gheorge et al. 2011; Örmeci et al. 2011; Wedemeyer et al. 2011, 2014; Karaca et al. 2013; Abbas et al. 2014). Studies performed with pegylated interferon for a duration of at least 1 and up to $2 \mathrm{yr}$ are summarized in Table 2. Response to treatment is assessed in the majority of publications at posttreatment week 24, and patients who are HDV RNA negative at this time point are considered to have a virologic response to treatment. Conventional or pegylated interferon therapy for $1 \mathrm{yr}$ leads to virologic response rates of around $25 \%$, which clearly underlines the need for treatment optimization and alternative treatment options.

Before commenting on responses to treatment, several issues need to be discussed. The first issue concerns valid surrogate markers of treatment efficacy. As with hepatitis B, HBsAg clearance would be an ideal surrogate marker of treatment efficacy. However, this is very rarely achieved, at least in a reasonable time frame. Thus, posttreatment month-six HDV RNA undetectability has been regarded as a reasonable surrogate of treatment efficacy, and by many as an indication for sustained virologic response, similar to treatment assessment in patients with chronic hepatitis C. However, Heidrich et al. (2014) was able to show that, on long-term follow-up of 16 posttreatment virologic responder patients of the Hep Net International Delta Intervention Trial (HIDIT)-1 study, nine patients tested HDV RNA positive at least once during 5 yr of follow-up. Rizzetto amd Smedile suggested that relapse after apparent successful treatment in $\mathrm{CDH}$ might be because of the high infectivity of HDV in the setting of established HBV infection (Rizzetto and Smedile 2015). HDV may remain infective at very low titers, as has been shown in early studies using chimpanzees in which infectious serum diluted as much as $10^{11}$ times was still able to transmit HDV to HBsAg-positive chimpanzees (Ponzetto et al. 
C. Yurdaydin and R. Idilman

Table 1. Controlled clinical trials of the use of interferons for the duration of at least 1 year

\begin{tabular}{|c|c|c|c|c|}
\hline References & Treatment schedule & $N$ & EOT VR & EOFU VR \\
\hline Rosina et al. 1991 & $\begin{array}{l}\text { IFN- } \alpha-2 b \text {, t.i.w., } 5 \mathrm{MU} / \mathrm{m}^{2} \times 4 \mathrm{mo}+ \\
\quad 3 \mathrm{MU} / \mathrm{m}^{2} \times 8 \mathrm{mo} \\
\text { No treatment }\end{array}$ & $\begin{array}{l}31 \\
30\end{array}$ & $\begin{array}{l}45 \% \\
27 \%\end{array}$ & $\begin{array}{l}\text { Not applicable } \\
\text { Not applicable }\end{array}$ \\
\hline Farci et al. 1994 & $\begin{array}{l}\text { IFN- } \alpha \text {-2a, t.i.w., } 9 \mathrm{MU} / \mathrm{m}^{2} \times 12 \mathrm{mo} \\
\text { IFN- } \alpha \text {-2a, t.i.w., } 3 \mathrm{MU} / \mathrm{m}^{2} \times 12 \mathrm{mo} \\
\text { No treatment }\end{array}$ & $\begin{array}{l}14 \\
14 \\
13\end{array}$ & $\begin{array}{r}71 \% \\
36 \% \\
0 \%\end{array}$ & $\begin{array}{r}43 \% \\
14 \% \\
8 \%\end{array}$ \\
\hline Gaudin et al. 1995 & $\begin{array}{l}\text { IFN- } \alpha \text { - } 2 \text { b, t.i.w., } 5 \mathrm{MU} / \mathrm{m}^{2} \times 4 \mathrm{mo}+ \\
\quad 3 \mathrm{MU} / \mathrm{m}^{2} \times 8 \mathrm{mo} \\
\text { No treatment }\end{array}$ & $\begin{array}{l}11 \\
11\end{array}$ & $\begin{array}{l}64 \% \\
36 \%\end{array}$ & $\begin{array}{l}18 \% \\
\text { Not applicable }\end{array}$ \\
\hline Madejon et al. 1994 & $\begin{array}{l}\text { IFN- } \alpha \text {-2a, t.i.w., } 18 \mathrm{MU} \times 6 \mathrm{mo}+9 \mathrm{MU} \times \\
1 \mathrm{mo}+6 \mathrm{MU} \times 1 \mathrm{mo}+ \\
3 \mathrm{MU} \times 4 \mathrm{mo} \\
\text { IFN- } \alpha \text {-2a, q.d., } 3 \mathrm{MU} \times 3 \mathrm{mo}+ \\
1.5 \mathrm{MU} \times 9 \mathrm{mo}\end{array}$ & $\begin{array}{l}16 \\
16\end{array}$ & $\begin{array}{l}31 \% \\
25 \%\end{array}$ & $\begin{array}{l}\text { Not applicable } \\
\text { Not applicable }\end{array}$ \\
\hline Günşar et al. 2005 & $\begin{array}{l}\text { IFN- } \alpha-2 \text { a, t.i.w., } 9 \mathrm{MU} \times 24 \mathrm{mo} \\
\text { IFN- } \alpha-2 \mathrm{a} \text {, t.i.w., } 9 \mathrm{MU} \times 24 \mathrm{mo}+ \\
\quad \text { ribavirin, } 1-1.2 \mathrm{~g} \text {, q.d. }\end{array}$ & $\begin{array}{l}10 \\
21\end{array}$ & $\begin{array}{l}50 \% \\
52 \%\end{array}$ & $\begin{array}{l}20 \% \\
24 \%\end{array}$ \\
\hline Canbakan et al. 2006 & $\begin{array}{l}\text { IFN- } \alpha \text {-2b, t.i.w., } 10 \mathrm{MU} \times 12 \mathrm{mo} \\
\text { IFN- } \alpha \text {-2b, t.i.w., } 10 \mathrm{MU} \times 12 \mathrm{mo}+ \\
\text { lamivudine }\end{array}$ & $\begin{array}{l}12 \\
14\end{array}$ & $\begin{array}{l}42 \% \\
64 \%\end{array}$ & $\begin{array}{l}17 \%^{\mathrm{a}} \\
29 \%^{\mathrm{a}}\end{array}$ \\
\hline Yurdaydin et al. 2008 & $\begin{array}{l}\text { IFN- } \alpha-2 a \text {, t.i.w., } 9 \mathrm{MU} \times 12 \mathrm{mo} \\
\text { IFN- } \alpha \text {-2a, t.i.w., } 9 \mathrm{MU} \times 12 \mathrm{mo}+ \\
\text { lamivudine }\end{array}$ & $\begin{array}{r}8 \\
14\end{array}$ & $\begin{array}{l}50 \% \\
50 \%\end{array}$ & $\begin{array}{l}50 \% \\
36 \%\end{array}$ \\
\hline
\end{tabular}

EOT, End of treatment; EOFU, end-of-treatment follow-up; VR, virologic response; IFN, interferon; t.i.w., three times a week; MU, megaunits; q.d., every day.

${ }^{\mathrm{a}}$ End of 6-12 months treatment-free follow-up (FU) except where mean FU was 3.1 years.

Table 2. Studies with pegylated interferon

\begin{tabular}{|c|c|c|c|c|}
\hline References & Treatment schedule & $N$ & EOT VR & EOFU VR \\
\hline \multirow[t]{2}{*}{ Niro et al. 2006} & Peg-IFN- $\alpha-2 b, 1.5 \mu \mathrm{g} / \mathrm{kg}$, q.w. $\times 18 \mathrm{mo}$ & 16 & $19 \%$ & $25 \%$ \\
\hline & $\begin{array}{l}\text { Peg-IFN- } \alpha-2 b, 1.5 \mu \mathrm{g} / \mathrm{kg} \text {, q.w. } \times 18 \mathrm{mo} \\
\quad+\text { ribavirin, } 1-1.2 \text { g, q.d. } \times 12 \mathrm{mo}\end{array}$ & 22 & $9 \%$ & $18 \%$ \\
\hline Castelnau et al. 2006 & Peg-IFN- $\alpha-2 b, 1.5 \mu \mathrm{g} / \mathrm{kg}$, q.w. $\times 12 \mathrm{mo}$ & 14 & $57 \%$ & $43 \%^{\mathrm{a}}$ \\
\hline Erhardt et al. 2006 & Peg-IFN- $\alpha-2 b, 1.5 \mu \mathrm{g} / \mathrm{kg}$, q.w. $\times 12 \mathrm{mo}$ & 12 & $17 \%$ & $17 \%$ \\
\hline \multirow[t]{2}{*}{ Wedemeyer et al. 2011} & Peg-IFN- $\alpha-2 a, 180 \mu$ g, q.w. $\times 12$ mo & 29 & $24 \%$ & $26 \%$ \\
\hline & $\begin{array}{l}\text { Peg-IFN- } \alpha-2 b, 180 \mu \text { g, q.w. } \times 12 \text { mo } \\
\quad+\text { adefovir, } 10 \mathrm{mg} \text {, q.d. }\end{array}$ & 31 & $23 \%$ & $31 \%$ \\
\hline Gheorge et al. 2011 & Peg-IFN- $\alpha-2 b, 1.5 \mu \mathrm{g} / \mathrm{kg}$, q.w. $\times 12 \mathrm{mo}$ & 48 & $33 \%$ & $25 \%$ \\
\hline \multirow[t]{2}{*}{ Örmeci et al. 2011} & Peg-IFN- $\alpha-2 b, 1.5 \mu \mathrm{g} / \mathrm{kg}$, q.w. $\times 24$ mo & 9 & $56 \%$ & $44 \%$ \\
\hline & Peg-IFN- $\alpha-2 b, 1.5 \mu \mathrm{g} / \mathrm{kg}$, q.w. $\times 12 \mathrm{mo}$ & 7 & $57 \%$ & $100 \%$ \\
\hline Abbas et al. 2014 & Peg-IFN- $\alpha-2 a, 180 \mu$ g, q.w. $\times 12$ mo & 104 & $42 \%$ & $23 \%$ \\
\hline Karaca et al. 2013 & $\begin{array}{l}\text { Peg-IFN- } \alpha-2 \mathrm{a}, 180 \mu \mathrm{g} \text {, or peg-IFN- } \alpha-2 \mathrm{~b} \\
1.5 \mu \mathrm{g} / \mathrm{kg}, \mathrm{q} . w . \times 24 \mathrm{mo}\end{array}$ & 32 & $50 \%$ & $47 \%^{\mathrm{b}}$ \\
\hline \multirow[t]{2}{*}{ Wedemeyer et al. 2014} & Peg-IFN- $\alpha-2 \mathrm{a}, 180 \mu \mathrm{g}, \mathrm{q} \cdot \mathrm{w} . \times 24 \mathrm{mo}$ & 61 & $33 \%$ & $21 \%$ \\
\hline & $\begin{array}{l}\text { Peg-IFN- } \alpha-2 \mathrm{a}, 180 \mu \mathrm{g} \text {, q.w. } \times 24 \mathrm{mo} \\
\quad+\text { tenofovir, } 300 \mathrm{mg} \text {, q.d. }\end{array}$ & 59 & $48 \%$ & $29 \%$ \\
\hline
\end{tabular}

Peg, Pegylated; q.w., every week.

${ }^{\mathrm{a}}$ End of 6 mo treatment-free FU except where median FU was 16 mo.

${ }^{\mathrm{b}}$ End of 6 mo treatment-free FU except where median FU was 6-60 mo. 
1987). It is noteworthy that, in $\mathrm{CDH}$, patients who may be HDV RNA positive at the end of treatment may become HDV RNA negative during posttreatment follow-up (Niro et al. 2006; Wedemeyer et al. 2011, 2014), further suggesting that any treatment end point transferred from the chronic hepatitis C literature is unlikely to be useful for HDV. On the other hand, in the study by Heidrich et al. (2014), none of the patients who had a virologic response at posttreatment week 24 developed a clinical event defined as liver-related mortality, liver transplantation, the development of hepatocellular cancer (HCC), or hepatic decompensation at long-term followup. All four patients who lost HBsAg during long-term follow-up had a posttreatment virologic response. This suggests that posttreatment week- 24 virologic response may still be clinically useful, and may be used as a treatment-assessment tool; however, the phrase "sustained virologic response" shall not be used.

Another important issue for consideration is the reliable measurement of serum HDV RNA. The lack of a standardized assay for HDV RNA measurements has been a significant problem in the studies mentioned to date. Even within reference laboratories, discordant results with the same serum samples have been observed (Le Gal et al. 2010). Fortunately, a World Health Organization (WHO) standard for HDV RNA measurement recently became available (Chudy et al. 2013), which will hopefully overcome the confusion related to HDV RNA measurements. The lack of standardized HDV RNA assays, so far, may to some extent explain the variations in the rates of sustained virologic responses reported in past studies as well as in recent studies with pegylated interferons (Castelnau et al. 2006; Erhardt et al. 2006; Niro et al. 2006; Wedemeyer et al. 2011). Additional factors contributing to the divergent virologic response rates of $17 \%-$ $43 \%$ in studies with pegylated interferon are the small sample sizes, the different drop-out rates affecting intention-to-treat analyses, and possible differences in baseline host and viral factors.

$\mathrm{CDH}$ is the most severe form of chronic viral hepatitis and, as such, patients with cirrhosis are much more frequently encountered in clinical trials with interferons. In the HIDIT-1 study, response to treatment of patients with advanced liver disease was found to be similar to that of nonadvanced liver disease (Kabaçam et al. 2012a). According to the results of the recently completed HIDIT-2 study, by far the largest study ever performed in $\mathrm{CDH}$ (Wedemeyer et al. 2014), patients with cirrhosis actually responded better than those with mild disease. However, it needs to be pointed out that, in the HIDIT- 1 study, out of 60 patients receiving pegylated interferon, there were two cases of hepatic decompensation, one case of tuberculosis reactivation, and, unfortunately, one fatality, all occurring among the 31 patients with advanced liver disease. On the other hand, in a study from Turkey with only treatment-naïve patients, the results were different (Günşar et al. 2005). In this study, none of the eight cirrhotic patients had a virologic response, whereas seven of 23 noncirrhotic patients had a virologic response $(p=0.07)$. It should be noted that patients with compensated cirrhosis represent a heterogeneous clinical spectrum (Everson et al. 2006) with variable degrees of portal hypertension; this differential feature is often not considered in the evaluation of response to therapy.

In chronic hepatitis $C$, accumulated evidence has indicated a difference in response to treatment between treatment-naïve patients and treatment-experienced patients. Patients who had a partial response or who had no response (null responder patients) to a previous course of treatment with pegylated interferon and ribavirin, respond to a second course less well compared to treatment-naïve patients. In contrast, in patients who have had a virologic response at end of treatment but then relapsed after treatment discontinuation, response to a subsequent course is better (EASL Clinical Practice Guidelines 2011; Ghany et al. 2011). Whether treatment-experienced patients respond to treatment as well as treatment-naïve patients is an unresolved issue in $\mathrm{CDH}$. In a study from Italy, being treatment naïve at baseline was an independent predictor of treatment efficacy (Niro et al. 2006). However, in the two largest studies performed in CDH, the HIDIT-1 and HIDIT-2 studies, no difference in posttreatment week-24 virologic response was observed 
between treatment-naïve patients and treatment-experienced patients (Wedemeyer et al. $2011,2014)$. In the only study in which this comparison was specifically addressed, no difference between treatment-naïve and treatment-experienced patients was observed in their response to treatment (Yurdaydin et al. 2008). It is likely that a certain bias exists in such trials in the context that patients who responded to a previous course and then relapsed would likely be more willing to receive another course of treatment compared to those who had not responded to treatment.

Treatment with interferons is associated with the burden of weekly injections and a plethora of side effects. To predict who will respond to treatment is an unmet need in CDH. Interleukin-28B polymorphisms do not appear to predict treatment response (Visco-Comandini et al. 2014; Yilmaz et al. 2014). A recent study on HDV RNA and HBsAg kinetics during pegylated interferon therapy has shown a biphasic HDV RNA decline with a first phase lasting a median of 25 days to be followed by a second phase with slower or no decline (Guedj et al. 2014). These data suggest that stopping rules can be developed for pegylated interferon therapy in $\mathrm{CDH}$. An ontreatment HDV RNA measurement can be used for treatment-response prediction (O Keskin, $\mathrm{H}$ Wedemeyer, A Tüzün, et al., unpubl.). In the HIDIT-1 study, earlier on-treatment time points could not be evaluated as those data were not available, but in a similar analysis of the HIDIT-2 study, earlier on-treatment time points did not perform as well as month-six HDV RNA measurements (Wöbse et al. 2014). On-treatment week-24 HDV RNA negativity had a positive predictive value (PPV) of $100 \%$ for posttreatment week-24 viral response (O Keskin, $\mathrm{H}$ Wedemeyer, A Tüzün, et al., unpubl.). Although these data confirmed the results of two previous studies (Castelnau et al. 2006; Yurdaydin et al. 2008), it is based on only five patients. On the other hand, a less than 1 log decline of HDV RNA at month six had a modest negative predictive value (NPV) of $75 \%$ for posttreatment week-24 virologic response (O Keskin, $\mathrm{H}$ Wedemeyer, ATüzün, et al., unpubl.). Currently, an early stopping rule recommendation cannot be made because of insufficient "power" in the above analyses.

Treatment with pegylated interferon in $\mathrm{CDH}$ should be for a duration of at least $1 \mathrm{yr}$, although optimal treatment duration is still not known. In several clinical studies, 2 yr of conventional or pegylated interferon treatment did not appear to provide higher virologic response rates compared to $1 \mathrm{yr}$ of treatment (Di Marco et al. 1996; Günşar et al. 2005; Yurdaydin et al. 2007; Örmeci et al. 2011). However, these were small clinical studies, and any conclusion based on those studies risks being misleading. The recently completed HIDIT-2 study, in which pegylated interferon-based treatment was administered for $2 \mathrm{yr}$, did not appear to increase posttreatment virologic response rates and was associated with high relapse rates after treatment cessation (Wedemeyer et al. 2014). However, beyond expert opinion, there is data, although limited, to suggest that patients may need treatment durations beyond 1 yr (Lau et al. 1999a; Kabaçam et al. 2011; Heller et al. 2014), but the length of treatment duration will probably be determined on an individual patient basis. Cumulative treatment durations up to 10 or $12 \mathrm{yr}$ have been reported (Lau et al. 1999a; Kabaçam et al. 2011). The need for a prolonged course of treatment with interferons is not surprising because, in assessing HDV RNA kinetics during pegylated interferon therapy, the estimated loss of infected cells, corresponding to the slow second phase of HDV RNA decline, was reported to be 10-20 times lower than what was found in $\mathrm{HCV}$ - or HBV-monoinfected patients treated with interferon, respectively (Neumann et al. 1998; Ribeiro et al. 2010; Guedj et al. 2014). Further, a long delay of a median of 8.5 days was observed before pegylated interferon had a significant effect in reducing HDV RNA levels in $\mathrm{CDH}$ (Guedj et al. 2014), again in contrast to the situation in $\mathrm{HBV}$ or $\mathrm{HCV}$ infection where this delay is only between 10 to $20 \mathrm{~h}$ (Dahari et al. 2010; Ribeiro et al. 2010). These data complement in vitro data that have consistently revealed a lack of effect of interferons on HDV RNA in cultured cells (Ilan et al. 1992; Chang et al. 2006) and that HDV itself might directly inhibit IFN$\alpha$ signaling (Pugnale et al. 2009). A recent study 
has shown that interferon can delay HDV entry into hepatocytes (Han et al. 2011). This suggests that the effectiveness of interferon therapy may involve blocking HDV spread to other hepatocytes rather than acting as a direct antiviral agent, which further rationalizes the need of long-term interferon treatment in $\mathrm{CDH}$.

Can other parameters be used beyond HDV RNA measurements to assess treatment efficacy? The clearance of HBsAg represents the ultimate treatment end point, and quantification of HBsAg could theoretically provide additional information. This is supported by data that show that successful interferon treatment is associated with a decrease not only in serum HDV RNA but also in quantitative HBsAg levels (Manesis et al. 2007). Further, a correlation has been observed between serum HDV RNA and HBsAg levels, but not with HBV DNA levels (Zachou et al. 2010). In the assessment of HDV RNA and HBsAg kinetics during pegylated interferon treatment, HBsAg kinetics paralleled the second phase of HDV RNA decline, and none of the patients with a flat second phase in HDV RNA and HBsAg developed a virologic response (Guedj et al. 2014). In a study aimed to develop stopping rules, on-treatment week-24 quantitative HBsAg levels predicted end-oftreatment and posttreatment week- 24 virologic response by univariate analysis. However, quantitative HBsAg levels failed to be an independent predictor of treatment efficacy in this analysis (O Keskin, H Wedemeyer, A Tüzün, et al., unpubl.). At this stage, no firm recommendation of the use of quantitative HBsAg for treatment assessment can be made, and future studies will be needed to understand the impact. Another potential easy-to-use parameter is a serologic marker, namely, anti-HDV IgM. The levels of anti-HDV IgM correlate with histological inflammatory activity and clinical long-term outcome. It is not as sensitive a measurement as HDV RNA in assessing treatment response, but patients who are anti-HDV IgM negative do not appear to develop on long-term follow-up a clinical event, such as hepatic decompensation, HCC, require liver transplantation, or suffer a liver-related death (Mederacke et al. 2012a; Wranke et al. 2014).
Several treatment algorithms have been proposed for $\mathrm{CDH}$ with interferons (Wedemeyer and Manns 2010; Yurdaydin et al. 2010, 2012; Hughes et al. 2011; Ciancio and Rizzetto 2014). Out of four, only one proposes a liver biopsy before commencing treatment. Two propose adding a nucleos(t)ide analog if HBV DNA is $>2000 \mathrm{IU} / \mathrm{mL}$. All algorithms base their pretreatment and end-of-treatment assessments on serum HDV RNA, two with and two without ALT assessments, while one algorithm recommends to monitor quantitative HBsAg levels as well. All four algorithms recommend $1 \mathrm{yr}$ of treatment, but propose to prolong treatment if HDV RNA levels remain detectable, or when relapse occurs after treatment discontinuation. Recently, Wedemeyer and colleagues proposed the so-called baseline-event-anticipation (BEA) score for treatment assessment (Calle Serano et al. 2014). The proposed algorithm developed by our group is depicted in Figure 1. It is important to check every patient with HBsAg positivity for HDV using anti-HDV serology. This is even more important in CHB patients with active disease. Overall, our group believes that a patient with HDV viremia and elevated transaminases should be started on pegylated IFN- $\alpha-2 \mathrm{a}$ or $\alpha-2 \mathrm{~b}$ for the duration of $1 \mathrm{yr}$ (Yurdaydin et al. 2012). If, at the end of treatment, HDV RNA is negative, treatment can be stopped and the patient followed closely posttreatment. In case of virologic relapse, treatment for another year is advised, especially when associated with elevated transaminases. After the second year of treatment, we suggest that the patient should be assessed with the same approach. In patients who show a partial virologic response after 1 yr of treatment (i.e., $>2 \log _{10}$ copies $/ \mathrm{mL}$ decline of HDV RNA), it is advised to continue treatment for a second year. Effective treatment of $\mathrm{CDH}$ appears to favorably affect disease progression (Farci et al. 2004; Manesis et al. 2013).

\section{COMBINATION TREATMENT WITH INTERFERONS AND NUCLEOS(T)IDE ANALOGS}

Combination treatments with interferons and antivirals against $\mathrm{HBV}$ have been explored 
C. Yurdaydin and R. Idilman

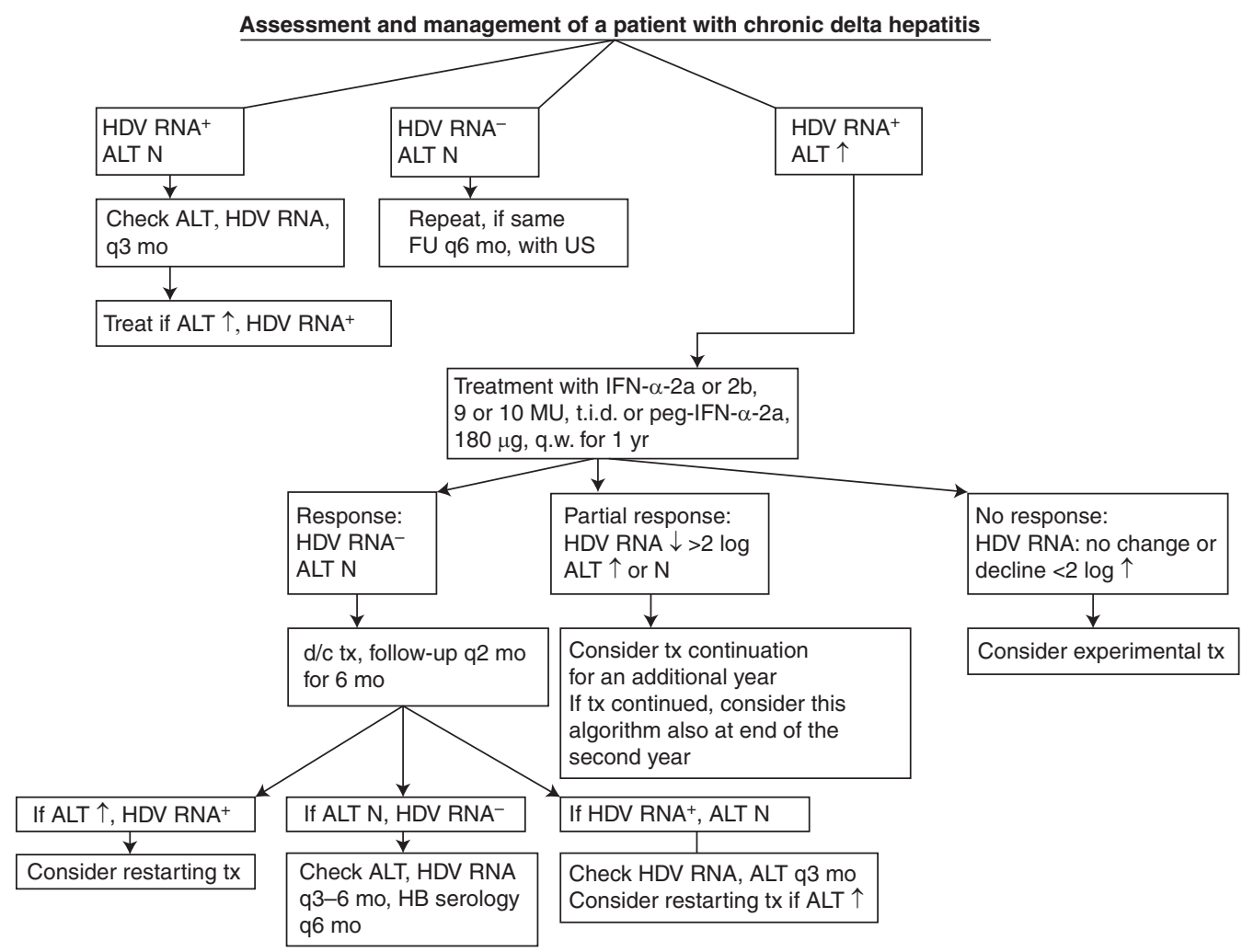

Figure 1. Suggested algorithm for the treatment of chronic delta hepatitis. HDV, Hepatitis D virus; q2/3/6 mo, every 2/3/6 months; peg, pegylated; IFN, interferon; t.i.d., three times a day; q.w., every week; $d / c$, discontinue; $\mathrm{N}$, Normal; $\uparrow$, increased; FU, follow-up; US, ultrasound; tx, treatment; ALT, alanine aminotransferase.

with the hope of enhancing response rates. Unfortunately, these attempts have been disappointing. No increase in virologic response was observed with the combination of IFN- $\alpha$ with lamivudine (Wolters et al. 2000; Canbakan et al. 2006; Yurdaydin et al. 2008). Likewise, the combination of conventional or pegylated interferon with ribavirin (Günşar et al. 2005; Kaymakoğlu et al. 2005; Niro et al. 2006) and the combination of adefovir with pegylated interferon (Wedemeyer et al. 2011) did not increase the virologic response compared to interferon monotherapy. However, the combination of pegylated interferon with adefovir was more effective compared to interferon monotherapy in reducing $\mathrm{HBsAg}$ levels (Wedemeyer et al. 2011). In the recently completed HIDIT-2 study, the impact of HBsAg decline was further assessed by comparing the combination of pegylated interferon with tenofovir versus pegylated interferon monotherapy
(Wedemeyer et al. 2014). In contrast to the pegylated interferon-adefovir combination, HBsAg decline was not different between the combination and monotherapy arms, and virologic response was also similar between groups. Thus, currently, the combination of pegylated interferon with NAs does not appear to provide additional benefit over monotherapy. However, some experts advocate the use of combination treatment in patients with high HBV viral load in their treatment algorithms (Wedemeyer and Manns 2010; Hughes et al. 2011). Further controlled studies are clearly needed.

\section{NA TREATMENT OF CDH}

The first NA tested for the treatment of $\mathrm{CDH}$ was ribavirin for which activity against both RNA and DNA viruses had been reported (Patterson 
and Fernandez-Larsson 1990). Ribavirin-induced inhibition of HDV replication in cultured primary woodchuck hepatocytes had been described (Choi et al. 1989). However, no virologic or biochemical effect was observed in human $\mathrm{CDH}$ when ribavirin was used (Garripoli et al. 1994). With the advent of NA therapy for the treatment of $\mathrm{CHB}$, it was hoped that NAs would also have an effect on $\mathrm{CDH}$, based on the assumption that by treating HBV the helper function exerted by this virus to support HDV infection would be abolished with a therapeutic benefit also for patients with $\mathrm{CDH}$. Several NAs have been tested in CDH for the last 15 years. Unfortunately, neither the less potent NAs, such as famciclovir (Yurdaydin et al. 2002) and adefovir (Wedemeyer et al. 2011), nor the intermediately potent lamivudine (Yurdaydin et al. 2008; Lau et al. 1999b; Niro et al. 2005a) and the more potent NA, such as entecavir (Kabaçam et al. 2012b), had a virologic or biochemical effect. The main reason for the disappointing results is that NAs cause inhibition of HBV DNA synthesis, but not the production of HBsAg, which is the primary function of HBV in support of the HDV life cycle. On the other hand, lamivudine is associated with resistance and the rtM204V and rtM204I substitutions in the polymerase gene lead to change in the overlapping $S$ gene, such as the $s W 196 L / S$, which inhibits HDV secretion (Vietheer et al.2005). The consequence of this compromised HDV secretion is unclear.

More promising results were observed in HDV patients coinfected with the human immunodeficiency virus (HIV); a significant decline of HDV RNA was observed in 13 of 16 patients treated mainly with tenofovir for a median of 6 yr (Sheldon et al. 2008), although the reason for this benefit is not clear. This study differed from the earlier studies using other NAs on two aspects: (1) the duration of treatment was much longer; and (2) the study population was coinfected with HIV. Both aspects probably need to be considered for a valid interpretation of this study. Prolonged treatment with tenofovir may have contributed indirectly by affecting HBsAg production through an overall decrease of HBV titers and perhaps a reduction in infected hepatocytes owing to the prolonged inhibi- tion of HBV DNA synthesis (Wursthorn et al. 2006). A significant decline of quantitative HBsAg levels during long-term treatment with NAs in HBeAg-negative HBV monoinfection would also support such reasoning (Manesis et al. 2011). On the other hand, another issue that needs to be considered is the effect of immune restoration during years of treatment with antiretroviral treatment of HIV infection. In a study on patients with HBV HIV coinfection, patients treated with antiretroviral treatment for a median duration of $2 \mathrm{yr}$, mean HBsAg levels decreased, whereas, in patients not receiving such treatment, HBsAg levels increased (Arendt et al. 2012). Further, among treated patients, those who had a decline in HBsAg levels had significantly higher baseline CD4 cell counts and also higher CD4 counts at the last followup compared to those whose HBsAg levels did not change (Arendt et al. 2012). Interestingly, in the study by Sheldon et al. (2008), a positive correlation was observed between serum HDV RNA and serum HBV DNA, which is different from HDV infection without HIV (Zachou et al. 2010), and may suggest immune pressure against both viruses. All of these data lend support for the notion that the beneficial effect of prolonged NA treatment in HDV HIV infection may be a consequence of immune restoration. Importantly, long-term studies of prolonged NA treatment in $\mathrm{CDH}$ without HIV infection still need to be completed.

An NA that raised particular interest in $\mathrm{CDH}$ was clevudine because, in the woodchuck hepatitis model, it inhibited the production of surface antigen in a dose-dependent manner (Peek et al. 2001) and, in a preliminary study, it was able to significantly decrease HDV RNA in woodchucks infected with HDV (Casey et al. 2005). Unfortunately, in a small pilot study in humans, clevudine was found to be ineffective (Yakut et al. 2010), and its further development was put on hold owing to the development of mitochondrial toxicity (Kim et al. 2009).

In HBV HDV coinfection, HDV is usually the dominant virus and represses $\mathrm{HBV}$ production, resulting in low or undetectable levels of HBV DNA in the blood (Schaper et al. 2010; Kabaçam et al. 2014). However, dynamic 
shifts of the dominant virus over time are also possible, and HBV levels increase and exceed those of HDV (Boyd et al. 2010; Schaper et al. 2010). Theoretically, NA could be effective in patients with $\mathrm{CDH}$ where $\mathrm{HBV}$ becomes the dominant virus (Yalçın et al. 2003; Kabaçam et al. 2012b). Further studies are needed to address these issues.

\section{OTHER THERAPIES}

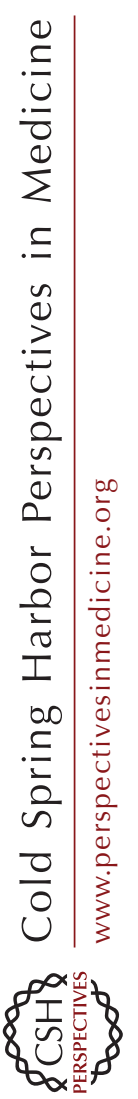

Two pilot studies reported on the use of thymusderived peptides for 6 mo with twice weekly intramuscular injections in CDH. Thymosin- $\alpha 1$, a 28-amino-acid polypeptide isolated from the bovine thymus extract thymosin fraction 5 , was tested in a small randomized study; one of five patients became HDV RNA negative and another patient who was HDV RNA negative at baseline but had HDAg in liver tissue achieved a biochemical response (Zavaglia et al. 1996). In another study, thymic humoral factor- $\gamma 2$, a thymus-derived synthetic octapeptide, was used in 11 patients; HDV RNA became undetectable in three of eight patients with HDV RNA detectable at baseline, of whom two had a virologic relapse (Rosina et al. 2002). Thymus-derived peptides are believed to have a variety of immunomodulatory effects (Katorza et al. 1987; Gosso et al. 1992), and beneficial effects were reported using a combination of thymic humoral factor- $\gamma 2$ with IFN- $\alpha$ in chronic hepatitis B (Farhat et al. 1995); however, no such combination has been tested in $\mathrm{CDH}$.

\section{TREATMENT OF PATIENTS WITH HDV-INDUCED DECOMPENSATED CIRRHOSIS}

Interferons are contraindicated in patients with decompensated cirrhosis. NAs may be considered as a bridge for liver transplantation. Liver transplantation is the only treatment option for patients with end-stage liver disease. Postliver transplantation HDV recurrence was less frequent and survival was better compared to HBV alone before the era of modern HBV prophylaxis for managing HBV recurrence (Samuel et al. 1993). As with HBV monoinfection, com- bination prophylaxis with hepatitis B immune globulin and NAs is the gold standard for prevention of recurrence and provides excellent recurrence-free survival rates in patients transplanted for HDV-induced liver disease (Grellier et al. 1996; Markowitz et al. 1998). One note of caution should still be applied; a recent study has shown HDV immunostaining up to 19 mo after liver transplantation (Mederacke et al. 2012b). This latency of HDV in the liver, reported also previously (Ottobrelli et al. 1991; Samuel et al. 1995), may increase the risk of rescuing HDV infection in case of reappearance of HBV, and patients with HDV may, therefore, not be suitable candidates for early hepatitis $\mathrm{B}$ immune globulin withdrawal after liver transplantation (Mederacke et al. 2012b).

\section{EMERGING TREATMENTS IN CDH}

It is likely that treatment in $\mathrm{CDH}$ will enter a new era in the foreseeable future where several steps of the HDV life cycle will be targeted. They include (1) attachment of HDV to the hepatocyte cell membrane; (2) uncoating in the cytoplasm and targeting of the ribonucleoprotein complex to the nucleus; (3) replication of new transcripts including mRNAs to form hepatitis delta antigen from antigenomic RNA and export of newly formed ribonucleoprotein complexes to the cytoplasm; (4) virion assembly in the cytoplasm, and (5) export of the new virion from the hepatocyte via the trans-Golgi network (Fig. 2) (Glenn 2005; Taylor 2006; Hughes et al. 2011). Two approaches have reached clinical stages of development and are currently being tested in phase- 2 human trials. They involve interventions with virus attachment to the hepatocyte via hepatocyte entry inhibitors and with $\mathrm{HDV}$ virion assembly via prenylation inhibitors.

\section{HEPATOCYTE ENTRY INHIBITORS}

As HBV surface proteins provide the envelope for HDV, it has been considered that both HBV and HDV share the same receptor for cellular attachment and entry, which appears to be indeed the case. Several studies have consistently 


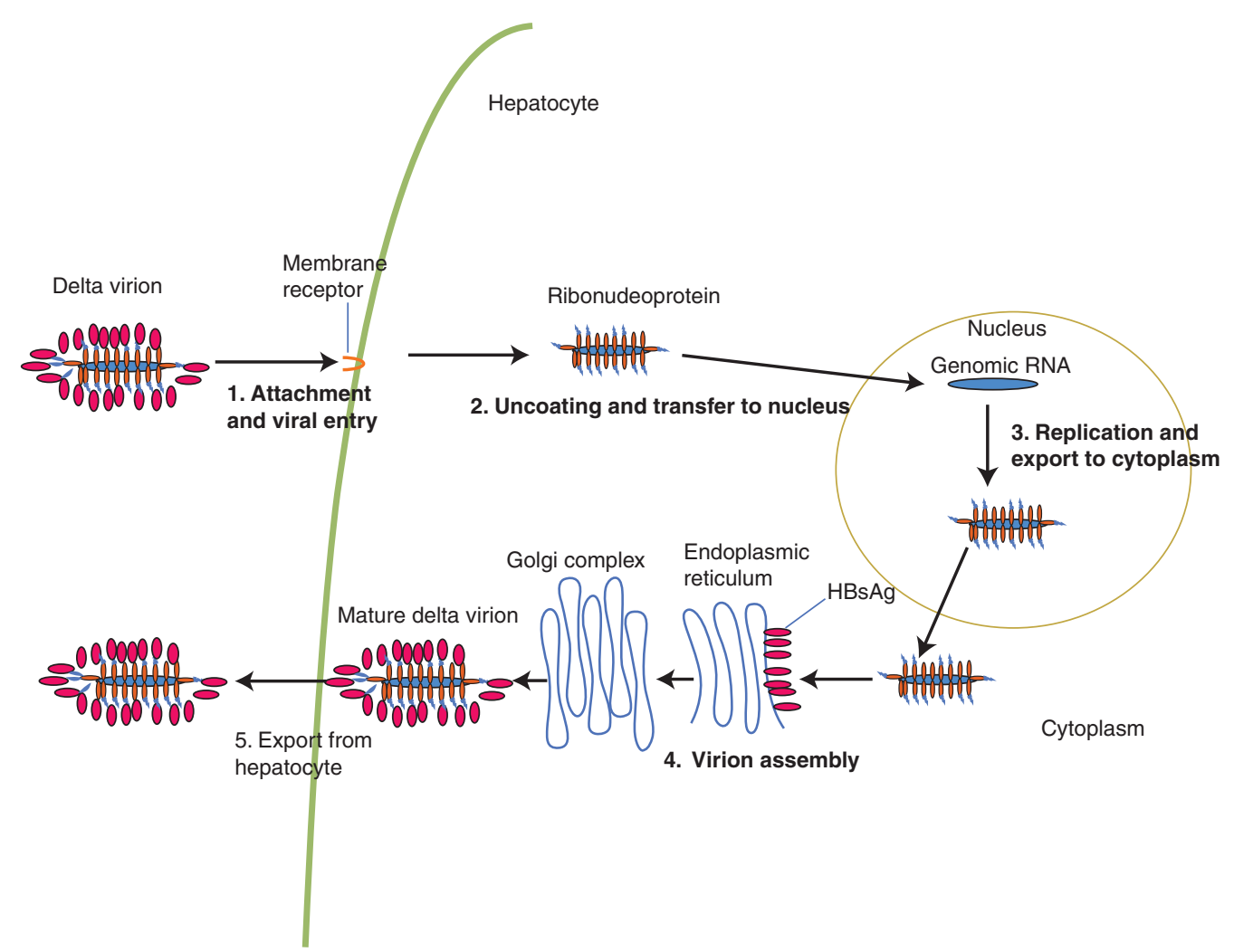

Figure 2. The hepatitis delta virus life cycle and potential targets for therapy. (1) Attachment to hepatocyte: the hepatitis B virus large antigen (or preS1) is crucial for attachment. (2) Uncoating and translocation to nucleus: transport to the nucleus is mediated most likely by the small delta antigen through its nuclear localizing signals. (3) Viral replication: viral replication occurs through a rolling circle model similar to plant viroids; of note is that HDV does not possess a polymerase of its own but uses RNA polymerase II of the host for this purpose. (4) Virion assembly: newly replicated HDV RNA and associated delta antigens are incorporated into an enveloped particle. (5) Export of the mature virion from the hepatocyte.

shown that the large $(\mathrm{L})$ surface protein of the HBV envelope is important for the step of cellular attachment of both HBV and HDV (Barrera et al. 2005; Engelke et al. 2006). Studies have also highlighted the importance of the integrity of the amino-terminal 77 amino acids in the preS1 domain and that myristoylation of glycine in the preS1 domain may be crucial for cellular attachment (Gripon et al. 1995; Blanchet and Sureau 2007). Abolishment of HBV infection by interfering with these properties has been shown both in vitro (Gripon et al. 1995; Blanchet and Sureau 2007) and in vivo (Petersen et al. 2008; Lütgehetmann et al. 2012). The first proof-of-concept human study showed that the HBV HDV entry inhibitor Myr- cludex B was well tolerated and that 6 mo daily subcutaneous administration led to $>1 \log _{10}$ reduction in HDV RNA in six of seven patients with CDH (Alexandrov et al. 2014). At week 24, one patient became HDV RNA negative while, with combination of Myrcludex B with pegylated interferon, five of seven patients became HDV RNA negative. Recently, sodium taurocholate cotransporting polypeptide (NTCP) has been identified as the functionally active specific receptor for HBV HDV (Yan et al. 2012) and is the target of Myrcludex B. This discovery will pave the way for drug development and screening for HDV HBV hepatocyte entry inhibition by using NTCP-based cell culture systems (Ni et al. 2013). 


\section{PRENYLATION INHIBITORS}

An important step of the HDV life cycle is virion assembly in which the newly formed ribonucleoprotein complexes consisting of delta RNA and antigen are covered by HBV envelope proteins. Prenylation of the large delta antigen is necessary for this step. The large delta antigen contains at its carboxyl terminal a cysteine residue containing a four-amino-acid motif that serves as a substrate for prenyltransferases (Glenn et al. 1992). Prenylation renders the protein more lipophilic and may help target large delta antigens to cellular membranes containing HBsAg. Two types of prenylation inhibitors are known, the farnesyltransferase and geranylgeranyltransferase inhibitors, of which the former is specific for HDV (Glenn 2005). Prenylation inhibitors specifically abolished HDV-like particle production in vitro (Bordier et al. 2002) and in vivo (Bordier et al. 2003). In a phase-2a double-blind, randomized, placebo-controlled clinical trial, $14 \mathrm{CDH}$ patients received twice a day orally $100 \mathrm{mg}$ or $200 \mathrm{mg}$ of the prenylation inhibitor lonafarnib for a duration of $28 \mathrm{~d}$ (Koh et al. 2014). The mean log HDV RNA reduction at day 28 from baseline was $-0.12 \mathrm{IU} / \mathrm{mL}$ with placebo $(p=0.31),-0.74 \mathrm{IU} / \mathrm{mL}$ with the lower dose $(p=0.02)$, and $-1.60 \mathrm{IU} / \mathrm{mL}$ with the higher dose of lonafarnib $(p<0.0001)$.

\section{RNA INTERFERENCE}

RNA interference (RNAi) mediates sequencespecific inhibition of gene expression via a posttranscriptional gene-silencing mechanism (Scherr and Eder 2007). ARC-520, a novel, short interfering RNA (siRNA)-containing, livertargeted therapeutic for treatment of $\mathrm{CHB}$, designed to reduce all HBV transcripts via RNA interference, was used in a randomized, doubleblind, placebo-controlled fashion in $\mathrm{HBeAg}$ negative CHB patients in a phase-IIa clinical trial (Yuen et al. 2014). Depth and duration of HBsAg decline and safety after a single intravenous injection of ARC-520 was assessed in 16 patients with $\mathrm{CHB}$. The drug was well tolerated at the two doses given and led to significant reduction of HBsAg levels versus placebo for days 3 through 43. Another siRNA-based approach tested in chimpanzees likewise reported a favorable response (Sepp-Lorenzino et al. 2014). Extension of these studies to patients with $\mathrm{CDH}$ is keenly awaited.

\section{IMMUNE THERAPEUTIC APPROACHES}

Several vaccination strategies have been tested for the treatment of CHB. Trials using conventional $\mathrm{HBV}$ vaccines were, in general, ineffective (Lu et al. 2007; Michel and Tiollais 2010). New approaches based on DNA vaccines or anti-HBs immune complexes are being tested in clinical trials (Mancini-Bourgine et al. 2004; Xu et al. 2013; Fontaine et al. 2015). A breakthrough success would let these approaches be considered for $\mathrm{CDH}$ treatment.

Another immune strategy involves Toll-like receptor (TLR) ligands. TLRs are inducers of type 1 interferon responses and play a key role in the induction of the innate immune system. Several preclinical studies using different TLR ligands have been performed (for review, see Zhang and Lu 2015). A phase II clinical study of the use of the TLR 7 ligand GS-9620 is underway in CHB. Overall, immune-mediated treatment approaches will likely be optimized as an adjunct to other treatment strategies.

\section{CONCLUSION}

Pegylated interferon treatment continues to be the only effective treatment in CDH. Duration of treatment should be no less than 1 year. The surrogate marker of treatment efficacy is quantitative HDV RNA measurement. Treatment duration beyond 1 year should be decided on an individual basis, and there is need of close follow-up of patients after treatment discontinuation. Interferons are contraindicated in patients with decompensated cirrhosis, and liver transplantation must be considered in such patients. An important issue is that HDV needs to be serologically tested for in every patient with $\mathrm{HBV}$ and, even more so, in patients with active hepatitis B infection. New therapeutic modalities are an urgent need in this most severe form of viral hepatitis. There is now hope that alter- 
native treatment options will become available within the next 5 years.

\section{REFERENCES}

Abbas Z, Memon MS, Mithani H, Jafri W, Hamid S. 2014. Treatment of hepatitis $\mathrm{D}$ patients with pegylated interferon: A real world experience. Antiviral Ther 19: 463-468.

Actis GC, Maran E, Rosina F, Saracco G, Rocca G, Rizzetto M, Bonino F, Verme G. 1987. Natural killer response to exogenous interferon in delta hepatitis: Boost or depression defined within the first week of therapy. Digestion 37: 51-58.

Alexandrov A, Lempp FA, Allweiss L, Bogomolov P, Voronkova N, Schwab M, Haag M, Wedemeyer H, Dandi M, Urban S. 2014. A proof-of-concept phase 2a clinical trial with HBV/HDV entry inhibitor Myrcludex. Hepatology 60 (Abstr.): LB-20.

Arendt E, Jaroszewicz J, Rockstroh J, Meyer-Olson D, Zacher BJ, Mederacke I, Manns MP, Wedemeyer H, Cornberg M, Wursthorn K. 2012. Improved immune status corresponds with long-term decline of quantitative serum hepatitis B surface antigen in HBV/HIV co-infected patients. Viral Immunol 25: 442-447.

Arrigoni A, Ponzetto A, Actis GC, Bonino F. 1983. Levamisole and chronic delta hepatitis. Ann Intern Med 98: 1024.

Barrera A, Guerra B, Notvall L, Lanford RE, Lanford RE. 2005. Mapping of the hepatitis B virus pre-S1 domain involved in receptor recognition. J Virol 79: 9786-9798.

Blanchet M, Sureau C. 2007. Infectivity determinants of the hepatitis B virus pre-S domain are confined to the $\mathrm{N}$ terminal 75 amino acid residues. J Virol 81: 5841-5849.

Bordier BB, Marion PL, Ohashi K, Kay MA, Greenberg HB, Casey JL, Glenn JS. 2002. A prenylation inhibitor prevents production of infectious hepatitis delta virus particles. J Virol 76: 10465-10472.

Bordier BB, Ohkanda J, Liu P, Lee SY, Salazar FH, Marion PL, Ohashi K, Meuse L, Kay MA, Casey JL, et al. 2003. In vivo antiviral efficacy of prenylation inhibitors against hepatitis delta virus. J Clin Invest 112: 407-414.

Boyd A, Lacombe K, Miailhes P, Gozlan J, Bonnard P, Molina JM, Lascoux-Combe C, Serfaty L, Gault E, Desvarieux M, et al. 2010. Longitudinal evaluation of viral interactions in treated HIV-hepatitis B co-infected patients with additional hepatitis $C$ and D virus. J Viral Hepat 17: 65-76.

Buti M, Homs, Rodriguez-Frias F, Funalleras G, Jardí R, Sauleda S, Tabernero D, Schaper M, Esteban R. 2011. Clinical outcome of acute and chronic hepatitis delta over time: A long-term follow-up study. J Viral Hepat 18: $434-442$.

Calle Serano B, Großhenning A, Homs M, Funalleras G, Jardí R, Sauleda S, Tabernero D, Schaper M, Esteban R. 2014. Development and evaluation of a baseline-eventanticipation score for hepatitis delta. J Viral Hepat 21: e154-e163.

Canbakan B, Șentürk H, Tabak F, Senturk H, Tabak F, Akdogan M, Tahan V, Mert A, Sut N, Ozaras R, et al. 2006. Efficacy of interferon $\alpha-2 b$ and lamivudine combination treatment in comparison to interferon $\alpha-2 b$ alone in chronic delta hepatitis: A randomized trial. J Gastroenterol Hepatol 21: 657-663.

Caredda F, Rossi E, d'Arminio Monforte A, Zampini L, Re T, Meroni B, Moroni M. 1985. Hepatitis B virus-associated coinfection and superinfection with delta agent: Indistinguishable disease with different outcome. J Infect Dis 151: 925-928.

Caredda F, Antinori S, Re T, Pastecchia C, Moroni M. 1987. Course and prognosis of acute HDV patients. Prog Clin Biol Res 364: 267-276.

Casey JL, Niro GA, Engle RE, Chu CK, Gerin JL, Hornbuckle WE, Tennant BC, Korba BE. 1996. Hepatitis B virus (HBV)/hepatitis D virus (HDV) coinfection in outbreaks of acute hepatitis in the Peruvian Amazon Basin: The roles of genotype III and HBV genotype F. J Infect Dis 174: 920-926.

Casey J, Cote PJ, Toshkov IA, Chu CK, Gerin JL, Hornbuckle WE, Tennant BC, Korba BE. 2005. Clevudine inhibits hepatitis delta virus viremia: A pilot study of chronically infected woodchucks. Antimicrob Agents Chemother 49: 4396-4399.

Castelnau C, Le Gal F, Ripault MP, Gordien E, MartinotPeignoux M, Boyer N, Pham BN, Maylin S, Bedossa P, Dény P, et al. 2006. Efficacy of peginterferon $\alpha-2 b$ in chronic hepatitis delta: Relevance of quantitative RTPCR for follow-up. Hepatology 44: 728-735.

Chang J, Nie X, Gudima S, Taylor J. 2006. Action of inhibitors on accumulation of processed hepatitis delta virus RNAs. J Virol 80: 3205-3214.

Choi SS, Rasshofer R, Roggendorf M. 1989. Inhibition of hepatitis delta virus RNA replication in primary woodchuck hepatocytes. Antiviral Res 12: 213-222.

Chudy M, Hanschmann K-M, Bozdayi AM, Kreß JC, Nübling M; WHO Expert Committee on Biological Standardization. 2013. Collaborative study to establish a World Health Organization international standard for hepatitis $\mathrm{D}$ virus RNA for nucleic acid amplification technique (NAT)-based assays. Geneva, Switzerland.

Ciancio A, Rizzetto M. 2014. Chronic hepatitis D at a standstill: Where do we go from here? Nat Rev Gastroenterol Hepatol 11: 68-71.

Dahari H, Affonso de Araujo ES, Haagmans BL, Layden TJ, Cotler SJ, Barone AA, Neumann AU. 2010. Pharmacodynamics of PEG-IFN- $\alpha$-2a in HIV-HCV co-infected patients: Implications for treatment outcomes. J Hepatol 53: 460-467.

Di Bisceglie AM, Martin P, Lisker-Melman M, Kassianides C, Korenman J, Bergasa NV, Baker B, Hoofnagle JH. 1990. Therapy of chronic delta hepatitis with interferon alfa $2 \mathrm{~b}$. J Hepatol 11: S151-154.

Di Marco V, Giacchino R, Timitilli A, Bortolotti F, Crivellaro C, Calzia R, Iannuzzi C, Prestileo T, Vajro P, Nebbia G; WHO Expert Committee on Biological Standardization. 1996. Collaborative study to establish a World Health Organization international standard for hepatitis $\mathrm{D}$ virus RNA for nucleic acid amplification technique (NAT)based assays. J Viral Hepat 3: 123-128.

EASL Clinical Practice Guidelines. 2011. Management of chronic hepatitis C virus infection. J Hepatol 55: 245264. 
EASL Clinical Practice Guidelines. 2012. Management of chronic hepatitis B virus infection. J Hepatol 57: 167185.

Engelke M, Mills K, Seitz S, Simon P, Gripon P, Schnölzer M Urban S. 2006. Characterization of a hepatitis B and hepatitis delta receptor binding site. Hepatology 43: $750-$ 760.

Erhardt A, Gerlich W, Starke C, Wend U, Donner A, Sagir A, Heintges T, Häussinger D. 2006. Treatment of chronic hepatitis delta with pegylated interferon- $\alpha 2 b$. Liver Int 26: $805-810$.

Everson GT, Hoefs JC, Seeff LB, Bonkovsky HL, Naishadham D, Shiffman ML, Kahn JA, Lok AS, Di Bisceglie AM, Lee WM, et al. 2006. Impact of severity on outcome of antiviral therapy for chronic hepatitis $\mathrm{C}$ : Lessons from the HALT-C trial. Hepatology 44: 1675-1684.

Farci P, Karayiannis P, Brook MG, Smedile A, Lai ME, Balestrieri A, Saldanha JA, Monjardino J, Gerin J, Thomas HC. 1989. Treatment of chronic hepatitis delta virus (HDV) infection with human lymphoblastoid $\alpha$ interferon. Quart J Med 73: 1045-1054.

Farci P, Mandas A, Coiana A, Lai ME, Desmet V, Van Eyken P, Gibo Y, Caruso L, Scaccabarozzi S, Criscuolo D, et al. 1994. Treatment of chronic hepatitis D with interferon alfa-2a. N Engl J Med 330: 88-94.

Farci P, Roskams T, Chessa L, Peddis G, Mazzoleni AP, Scioscia R, Serra G, Lai ME, Loy M, Caruso L, et al. 2004. Long-term benefit of interferon $\alpha$ therapy of chronic hepatitis D: Regression of advanced hepatic fibrosis. Gastroenterology 126: $1740-1749$.

Farhat BA, Marinos G, Daniels HM, Naumov N, Williams R. 1995. Evaluation of efficacy and safety of thymus humoral factor- $\gamma 2$ in the management of chronic hepatitis B. J Hepatol 23: 21-27.

Fontaine H, Kahi S, Chazallon C, Bourgine M, Varaut A, Buffet C, Godon O, Meritet JF, Saïdi Y, Michel ML, et al. 2015. Anti-HBV DNA vaccination does not prevent relapse after discontinuation of analogues in the treatment of chronic hepatitis B: A randomized trial-ANRS HB02 VAC-ADN. Gut 64: 139-147.

Fung J, Lai CL, Seto WK, Yuen MF. 2011. Nucleoside/nucleotide analogues in the treatment of chronic hepatitis B. J Antimicrob Chemother 66: 2715-2725.

Garripoli V, Di Marco V, Cozzolongo R, Costa C, Smedile A, Fabiano A, Bonino F, Rizzetto M, Verme G, Craxi A, et al. 1994. Ribavirin treatment for chronic hepatitis D: A pilot study. Liver 14: 154-157.

Gaudin JL, Faure P, Godinot H, Gerard F, Trepo C. 1995. The French experience of treatment of chronic type D hepatitis with a 12-month course of interferon $\alpha-2 B$. Results of a randomized controlled trial. Liver 15: 45-52.

Ghany MG, Nelson DR, Strader DB, Thomas DL, Seeff LB. 2011. An update on treatment of genotype 1 chronic hepatitis $\mathrm{C}$ virus infection: 2011 practice guideline by the American Association for the Study of Liver Diseases. Hepatology 54: 1433-1444.

Gheorge L, Iacob S, Simionov I, Vadan R, Constantinescu I, Caruntu F, Sporea I, Grigorescu M. 2011. Weight-based dosing regimen of peg-interferon $\alpha-2 b$ for chronic hepatitis delta: A multicenter Romanian trial. J Gastrointestinal Liver Dis 20: 377-382.
Glenn JS. 2005. Prenylation of HDAg and antiviral drug development. Curr Top Microbiol Immunol 307: 133149.

Glenn JS, Watson JA, Havel CM, White JM. 1992. Identification of a prenylation site in delta virus large antigen. Science 256: 1331-1333.

Gosso C, Frasca D, Doria G. 1992. Effect of synthetic thymic humoral factor (THF- $\gamma 2$ ) on T cell activities on immunodeficient aging mice. Clin Exp Immunol 87: 346-335.

Govindarajan S, Chin KP, Redeker AG, Peters RL. 1984. Fulminant B viral hepatitis: Role of delta agent. Gastroenterology 86: 1417-1420.

Grabowski J, Wedemeyer H. 2010. Hepatitis delta: Immune pathogenesis and clinical challenges. Dig Dis 28: $133-$ 138.

Grabowski J, Yurdaydin C, Zachou K, Buggisch P, Hofmann WP, Jaroszewicz J, Schlaphoff V, Manns MP, Cornberg M Wedemeyer H, et al. 2011. Hepatitis D virus-specific cytokine responses in patients with chronic hepatitis delta before and during interferon alfa-treatment. Liver Int 31: 1395-1405.

Greco-Stewart VS, Schissel E, Pelchat M. 2009. The hepatitis delta virus RNA genome interacts with the human RNA polymerases I and III. Virology 386: 12-15.

Grellier L, Mutimer D, Ahmed M, Brown D, Burroughs AK, Rolles K, McMaster P, Beranek P, Kennedy F, Kibbler H, et al. 1996. Lamivudine prophylaxis against reinfection in liver transplantation for hepatitis B cirrhosis. Lancet 348: 1212-1215.

Gripon P, Le Seyec J, Rumin S, Guguen-Guillouzo C. 1995. Myristylation of the hepatitis B virus large surface protein is essential for viral infectivity. Virology 213: 292-299.

Guedj J, Rotman Y, Cotler SJ, Koh C, Schmid P, Albrecht J, Haynes-Williams V, Liang TJ, Hoofnagle JH, Heller T, et al. 2014. Understanding early serum hepatitis $\mathrm{D}$ virus and hepatitis B surface antigen kinetics during pegylated interferon- $\alpha$ therapy via mathematical modeling. Hepatology 60: 1902-1910.

Gunsar F, Akarca US, Ersoz G, Kobak AC, Karasu Z, Yuce G, Ilter T, Batur Y. 2005. Two-year interferon therapy with or without ribavirin in chronic delta hepatitis. Antivir Ther 10: 721-726.

Han Z, Nogusa S, Nicolas E, Balachandran S, Taylor J. 2011. Interferon impedes an early step of hepatitis delta virus infection. PloS ONE 6: e22415.

Heidrich B, Yurdaydin C, Kabaçam G, Ratsch BA, Zachou K, Bremer B, Dalekos GN, Erhardt A, Tabak F, Yalçın K, et al. 2014. Late HDV RNA relapse after peginterferon $\alpha$-based therapy of chronic hepatitis delta. Hepatology 60: 87-97.

Heller T, Rotman Y, Koh C, Clark S, Haynes-Williams V, Chang R, McBurney R, Schmid P, Albrecht J, Kleiner $\mathrm{DE}$, et al. 2014. Long term therapy of chronic delta hepatitis with peginterferon alfa. Aliment Pharmacol Ther 40: 93-104.

Hughes SA, Wedemeyer H, Harrison PH. 2011. Hepatitis delta virus. Lancet 378: 73-85.

Ilan YM, Klein A, Taylor J, Tur-Kaspa R. 1992. Resistance of hepatitis delta virus replication to $\alpha$ interferon treatment in transfected human cells. J Infect Dis 166: 1164-1166

Kabaçam G, Yakut M, Seven G, Karatayli SC, Nassiri C, Bozkaya H, Bozdayi AM, Idilman R, Yurdaydin C. 2011. 
Delta hepatitis may require prolonged treatment with interferon. Hepatology 54: p1039A.

Kabaçam G, Dalekos GN, Cakaloğlu Y, Zachou K, Bock T, Erhardt A, Zeuzem S, Tabak F, Yalçın K, Bozdayi AM, et al. 2012a. Pegylated interferon-based treatment in patients with advanced liver disease due to chronic delta hepatitis. Turk J Gastroenterol 23: 560-568.

Kabaçam G, Önder FO, Yakut M, Seven G, Karatayli SC, Karatayli E, Savas B, Idilman R, Bozdayi AM, Yurdaydin C. 2012b. Entecavir treatment of chronic hepatitis D. Clin Infect Dis 55: 645-650.

Kabaçam G, Wedemeyer H, Savas B, Savaş B, Keskin O, Dalekos G, Tabak F, Idilman R, Erhardt A, Yalçın K, et al. 2014. Role of immunohistochemistry for hepatitis D and hepatitis B virus in hepatitis delta. Liver Int 34: 107 115.

Karaca C, Soer OM, Baran B, Ormeci AC, Gokturk S, Aydin E, Evirgen S, Akyuz F, Demir K, Besisik F, et al. 2013. Efficacy of pegylated interferon- $\alpha$ treatment for 24 months in chronic delta hepatitis and predictors of response. Antiviral Ther 18: 561-566.

Karatayli SC, Ulger ZE, Ergul AA, Keskin O, Karatayli E, Albayrak R, Ozkan M, Idilman R, Yalçın K, Bozkaya H, et al. 2014. Tumour necrosis factor $\alpha$, interleukin-10, interferon- $\gamma$ and vitamin D receptor gene polymorphisms in patients with chronic hepatitis delta. J Viral Hepat 21: 297-304.

Katorza E, Pecht M, Apte RN, Benharroch D, Burstein Y, Trainin N, Rager-Zisman B. 1987. Restoration of immunological response by THF, a thymic hormone, in mice infected with murine cytomegalovirus (MCMV). Clin Exp Immunol 70: 268-275.

Kaymakoglu S, Karaca C, Demir K, Poturoglu S, Danalioglu A, Badur S, Bozaci M, Besisik F, Cakaloglu Y, Okten A. 2005. $\alpha$-Interferon and ribavirin combination therapy of chronic hepatitis D. Antimicrob Agents Chemother 49: $1135-1138$.

Kim BK, Oh J, Kwon SY, Choe WH, Ko SY, Rhee KH, Seo TH, Lim SD, Lee CH. 2009. Clevudine myopathy in patients with chronic hepatitis B. J Hepatol 51: 787-791.

Koh C, Yurdaydin C, Cooper S, Cory D, Dhari H, HaynesWilliams V, Winters MA, Bys M, Choong I, Idilman R, et al. 2014. Prenylation Inhibition with lonafarnib decreases hepatitis D levels in humans. Hepatology 60: 1092A1093A.

Lau DT, Doo E, Park Y, Kleiner DE, Schmid P, Kuhns MC, Hoofnagle JH. 1999a. Lamivudine for chronic delta hepatitis. Hepatology 30: 546-549.

Lau DT, Kleiner DE, Park Y, Di Bisceglie AM, Hoofnagle JH. 1999b. Resolution of chronic delta hepatitis after 12 years of interferon alfa therapy. Gastroenterology 117: 12291233.

Le Gal F, Brichler S, Checkaraou MA, et al. 2010. Results of a French national quality control for hepatitis delta virus RNA quantification. In EASL Monothematic Conference on Delta Hepatitis, Abstract Book, 98 pp. Istanbul, Turkey.

Lok ASF, McMahon BJ. 2009. Chronic hepatitis B: Update 2009. Hepatology 50: 661-662.

Lu M, Menne S, Yang D, Xu Y, Roggendorf M. 2007. Immunomodulation as an option for the treatment of chronic hepatitis B virus infection: Preclinical studies in the woodchuck model. Expert Opin Investig Drugs 16: 787 801.

Lunemann S, Malone DF, Hengst J, Port K, Grabowski J, Deterding K, Markova A, Bremer B, Schlaphoff V, Cornberg M, et al. 2014. Compromised function of natural killer cells in acute and chronic viral hepatitis. J Infect Dis 208: 1362-1373.

Lütgehetmann M, Mancke LV, Volz T, Helbig M, Allweiss L, Bornscheuer T, Pollok JM, Lohse AW, Petersen J, Urban S, et al. 2012. Humanized chimeric uPA mouse model for the study of hepatitis $\mathrm{B}$ and $\mathrm{D}$ virus interactions and preclinical drug evaluation. Hepatology 55: 685-694.

Madejon A, Cotonat T, Bartolome J, Castillo I, Carreno V. 1994. Treatment of chronic hepatitis D virus infection with low and high doses of interferon- $\alpha$ 2a: Utility of polymerase chain reaction in monitoring antiviral response. Hepatology 19: 1331-1336.

Mancini-Bourgine M, Fontaine H, Scott-Algara D, Pol S, Bréchot C, Michel ML. 2004. Induction or expansion of T-cell responses by a hepatitis B DNA vaccine administered to chronic HBV carriers. Hepatology 40: 874-882.

Manesis EK, Schina M, Le Gal F, Agelopoulou O, Papaioannou C, Kalligeros C, Arseniou V, Manolakopoulos S, Hadziyannis ES, et al. 2007. Quantitative analysis of hepatitis D virus RNA and hepatitis B surface antigen serum levels in chronic delta hepatitis improves treatment monitoring. Antiviral Ther 12: 381-388.

Manesis EK, Papatheodoridis GV, Tiniakos DG, Hadziyannis ES, Agelopoulou OP, Syminelaki T, Papaioannou C, Nastos T, Karayiannis P. 2011. Hepatitis B surface antigen: Relation to hepatitis B replication parameters in $\mathrm{HBeAg}$ negative chronic hepatitis B. J Hepatol 55: 61-68.

Manesis EK, Vourli G, Dalekos G, Vasiliadis T, Manolaki N, Hounta A, Koutsounas S, Vafiadis I, Nikolopoulou G, Giannoulis G, et al. 2013. Prevalence and clinical course of hepatitis delta infection in Greece: A 13-year prospective study. J Hepatol 59: 949-956.

Markowitz JS, Martin P, Conrad AJ, Markmann JF, Seu P, Yersiz H, Goss JA, Schmidt P, Pakrasi A, Artinian L, et al. 1998. Prophylaxis against hepatitis B recurrence following liver transplantation using combination lamivudine and hepatitis B immune globulin. Hepatology 28: 585589.

Mederacke I, Filmann N, Yurdaydin C, Bremer B, Puls F, Zacher BJ, Heidrich B, Tillmann HL, Rosenau J, Bock CT, et al. 2012a. Rapid early HDV RNA decline in the peripheral blood but prolonged intrahepatic hepatitis delta antigen persistence after liver transplantation. $J$ Hepatol 56: 115-122.

Mederacke I, Yurdaydin C, Dalekos GN, Bremer B, Erhardt A, Cakaloglu Y, Yalçın K, Gurel S, Zeuzem S, Zachou K, et al. 2012b. Anti-HDV immunoglobulin M testing in hepatitis delta revisited: Correlations with disease activity and response to pegylated interferon- $\alpha 2 \mathrm{a}$ treatment. $A n-$ tiviral Ther 17: 305-312.

Michel ML, Tiollais P. 2010. Hepatitis B vaccines: Protective efficacy and therapeutic potential. Pathol Biol (Paris) 58: 288-295.

Neumann AU, Lam NP, Dahari H, Gretch DR, Wiley TE, Layden TJ, Perelson AS. 1998. Hepatitis C virus dynamics in vivo and the antiviral efficacy of interferon- $\alpha$ therapy. Science 282: 103-107. 
Ni Y, Lempp FA, Mehrle S, Nkongolo S, Kaufman C, Fälth M, Stindt J, Königer C, Nassal M, Kubitz R, et al. 2013. Hepatitis B and D viruses exploit sodium taurocholate co-transporting polypeptide for species-specific entry into hepatocytes. Gastroenterology 146: 1070-1083.

Niro GA, Ciancio A, Tillman HL, Lagget M, Olivero A, Perri F, Fontana R, Little N, Campbell F, Smedile A, et al. 2005a. Lamivudine therapy in chronic delta hepatitis: A multicentre randomized-controlled pilot study. Aliment Pharmacol Ther 22: 227-232.

Niro GA, Rosina F, Rizzetto M. 2005b. Treatment of hepatitis D. J Viral Hepat 12: 2-9.

Niro GA, Ciancio A, Gaeta GB, Smedile A, Marrone A, Olivero A, Stanzione M, David E, Brancaccio G, Fontana $R$, et al. 2006. Pegylated interferon $\alpha-2 b$ as monotherapy or in combination with ribavirin in chronic hepatitis delta. Hepatology 44: 713-720.

Ormeci N, Bölükbaş F, Erden E, Coban S, Ekiz F, Erdem H, Palabıyıkoğlu M, Beyler AR, Balık I, Bölükbaş C, et al. 2011. Pegylated interferon alfa-2B for chronic delta hepatitis: 12 versus 24 months. Hepatogastroenterology 58: 1648-1653.

Ottobrelli A, Marzano A, Smedile A, Recchia S, Salizzoni M, Cornu C, Lamy ME, Otte JB, De Hemptinne B, Geubel A, et al. 1991. Patterns of hepatitis delta-virus reinfection and disease in liver-transplantation. Gastroenterology 101: 1649-1655.

Patterson JL, Fernandez-Larsson R. 1990. Molecular mechanisms of action of ribavirin. Rev Infect Dis 12: 11391146.

Peek SF, Cote PJ, Jacob JR, Toshkov IA, Hornbuckle WE, Baldwin BH, Wells FV, Chu CK, Gerin JL, Tennant BC, et al. 2001. Antiviral activity of clevudine [1-FMAU, 1-(2fluoro-5-methyl- $\beta$, 1-arabinofuranosyl) uracil] against woodchuck hepatitis virus replication and gene expression in chronically infected woodchucks. Hepatology 33: 254-266.

Petersen J, Dandri M, Mier W, Lütgehetmann M, Volz T, von Weizsäcker F, Haberkorn U, Fischer L, Pollok JM, Erbes B, et al. 2008. Prevention of hepatitis B virus infection in vivo by entry inhibitors derived from the large envelope protein. Nat Biotechnol 26: 335-341.

Ponzetto A, Hoyer BH, Popper H, Engle R, Purcell RH, Gerin JL. 1987. Titration of the infectivity of hepatitis $\mathrm{D}$ virus in chimpanzees. J Infect Dis 155: 72-78.

Pugnale P, Pazienza V, Guilloux K, Negro F. 2009. Hepatitis delta virus inhibits $\alpha$ interferon signaling. Hepatology 49: 398-406.

Ribeiro RM, Germanidis G, Powers KA, Pellegrin B, Nikolaidis P, Perelson AS, Pawlotsky JM. 2010. Hepatitis B virus kinetics under antiviral therapy sheds light on differences in hepatitis B e antigen positive and negative infections. J Infect Dis 202: 1309-1318.

Rizzetto M. 2009. Hepatitis D: Thirty years after. J Hepatol 50: $1043-1050$.

Rizzetto M, Smedile A. 2015. Pegylated therapy of chronic hepatitis D: In need of revision. Hepatology 61: 1109_ 1111.

Rizzetto M, Canese MG, Aricò S, Crivelli O, Trepo C, Bonino F, Verme G. 1977. Immunofluorescence detection of new antigen-antibody system (delta/anti-delta) associat- ed to hepatitis B virus in liver and in serum of HBsAg carriers. Gut 18: 997-1003

Rizzetto M, Canese MG, Gerin JL, London WT, Sly DL, Purcell RH. 1980. Transmission of hepatitis B virus-associated delta antigen in chimpanzees. J Infect Dis 141: 590-602.

Rizzetto M, Verme G, Recchia S, Bonino F, Farci P, Aricò S, Calzia R, Picciotto A, Colombo M, Popper H. 1983. Chronic hepatitis in carriers of hepatitis B surface antigen, with intrahepatic expression of the delta antigen. An active and progressive disease unresponsive to immunosuppressive treatment. Ann Intern Med 98: 437-41.

Rosina F, Saracco G, Sansalvadore F. 1989. $\alpha$-Interferon in the treatment of chronic delta hepatitis. Ital J Gastroenterol 21: 141-145.

Rosina F, Pintus C, Meschievitz C, Rizzetto M. 1991. A randomized controlled clinical trial of a 12 month course of recombinant human interferon- $\alpha$ in chronic hepatitis delta hepatitis: A multicenter Italian study. Hepatology 13: 1052-1056.

Rosina F, Conoscitore P, Smedile A, Mangia A, Borghesio E, Martinotti R, Andriulli A, Rizzetto M. 2002. Treatment of chronic hepatitis D with thymus-derived polypeptide thymic humoral factor- $\gamma$ 2: A pilot study. Dig Liver Dis 34: $285-289$.

Samuel D, Muller D, Alexander G, Fassati L, Ducot B, Benhamou JP, Bismuth H. 1993. Liver transplantation in European patients with the hepatitis B surface antigen. N Engl J Med 329: 1842-1847.

Samuel D, Zignego AL, Reynes M, Feray C, Arulnaden JL, David MF, Gigou M, Bismuth A, Mathieu D, Gentilini P, et al. 1995. Long-term clinical and virological outcome after liver transplantation for cirrhosis caused by chronic delta hepatitis. Hepatology 21: 333-339.

Sánchez-Tapias JM, Mas A, Costa J, Bruguera M, Mayor A, Ballesta AM, Compernolle C, Rodés J. 1987. Recombinant $\alpha 2 \mathrm{c}$-interferon therapy in fulminant viral hepatitis. J Hepatol 5: 205-210.

Schaper M, Rodriguez-Frias F, Jardi R, Tabernero D, Homs M, Ruiz G, Quer J, Esteban R, Buti M. 2010. Quantitative longitudinal evaluations of hepatitis delta virus RNA and hepatitis B virus DNA shows a dynamic, complex replicative profile in chronic hepatitis B and D. J Hepatol 52: $658-664$.

Scherr M, Eder M. 2007. Gene silencing by small regulatory RNAs in mammalian cells. Cell Cycle 6: 444-449.

Sepp-Lorenzino L, Abrams M, Carayannopoulos L, Koser M, Ludmerer S, Charusse JB, Freedman D, Jadhav V, Raheev JG, Hinkle G, et al. 2014. ALN-HBV, a GalNAcsiRNA enhanced stabilization chemistry RNAi therapeutic for the treatment of chronic hepatitis B virus infection. Hepatology 60 (Abstr): 1091A.

Sheldon J, Ramos B, Toro C, Ríos P, Martínez-Alarcón J, Bottecchia M, Romero M, Garcia-Samaniego J, Soriano V. 2008. Does treatment of hepatitis B virus infection reduce hepatitis delta virus replication in HIV-HBVHDV-coinfected patients? Antiviral Ther 13: 97-102.

Smedile A, Farci P, Verme G, Caredda F, Cargnel A, Caporaso N, Dentico P, Trepo C, Opolon P, Gimson A, et al. 1982. Influence of delta infection on severity of hepatitis B. Lancet ii: 945-947. 
Taylor JM. 2006. Structure and replication of hepatitis delta virus RNA. Curr Top Microbiol Immunol 307: 1-23.

Taylor JM. 2012. Virology of hepatitis D virus. Semin Liver Dis 32: 195-200.

Urban S, Bogomolov P, Voronkova N, Allweiss L, Dandri M, Schwab M, Lemp FA, Haag M, Wedemeyer H, Alexandrov A. 2014. A proof-of-concept Phase 2a clinical trial with HBV/HDV entry inhibitor Myrcludex B. Hepatology 60 (Abstr): LB-20.

Vietheer PT, Netter HJ, Sozzi T, Bartholomeusz A. 2005. Failure of the lamivudine-resistant rtM204I hepatitis B virus mutants to efficiently support hepatitis delta virus secretion. J Virol 79: 6570-6573.

Visco-Comandini U, Lapa D, Taibi C, Angeletti C. 2014. No impact of interleukin-28B polymorphisms on spontaneous or drug-induced hepatitis delta virus clearance. Dig Liver Dis 46: 348-352.

Wagstaff AJ, Bryson HM. 1994. Foscarnet. A reappraisal of its antiviral activity, pharmacokinetic properties and therapeutic use in immunocompromised patients with viral infections. Drugs 48: 199-226.

Wedemeyer H, Manns MP. 2010. Epidemiology, pathogenesis and management of delta hepatitis: Update and challenges ahead. Nat Rev Gastroenterol Hepatol 7: 31-40.

Wedemeyer H, Yurdaydin C, Dalekos GN, Erhardt A, Çakaloğlu Y, Değertekin H, Gürel S, Zeuzem S, Zachou K, Bozkaya H, et al. 2011. Peginterferon plus adefovir versus either drug alone for hepatitis delta. $N$ Engl J Med 364: 322-331.

Wedemeyer H, Yurdaydin C, Ernst S, Caruntu FA, Curescu MG, Yalcin K, Akarca US, Gurel S, Zeuzem S, Erhardt A, et al. 2014. Prolonged therapy of hepatitis delta for 96 weeks with pegylated interferon- $\alpha-2$ a plus tenofovir or placebo does not prevent HDV RNA relapse after treatment: the HIDIT-2 study. J Hepatol 60 (Abstr): S2-S3.

Wöbse M, Yurdaydin C, Ernst S, Hardtke S, Heidrich B, Bremer B, Keskin O, Idilman R, Koch A, Manns MP, Wedemeyer H, Hardtke S, Heidrich B. 2014. Early ontreatment HDV RNA kinetics are not predictive for longterm response to a Peg-IFN therapy of hepatitis delta. Hepatology 60 (Abstr): 974A.

Wolters LM, van Nunen AB, Honkoop P, Vossen AC, Niesters HG, Zondervan PE, de Man RA. 2000. Lamivudinehigh dose interferon combination therapy for chronic hepatitis B patients co-infected with the hepatitis D virus. J Viral Hepat 7: 428-434.

Wranke A, Heidrich B, Ernst S, Calle Serrano B, Caruntu FA, Curescu MG, Yalcin K, Gürel S, Zeuzem S, Erhardt A, et al. 2014. Anti HDV IgM as a marker of disease activity in hepatitis delta. PLoS ONE 9: e101002.

Wursthorn K, Lütgehetmann M, Dandri M, Volz T, Buggisch P, Zollner B, Longerich T, Schirmacher P, Metzler F, Zankel M, et al. 2006. Peginterferon $\alpha$ 2b plus adefovir induce strong cccDNA decline and HBsAg reduction in patients with chronic hepatitis B. Hepatology 44: 675684.

Xu DZ, Wang XY, Shen XL, Gong GZ, Ren H, Guo LM, Sun AM, Xu M, Li LJ, Guo XH, et al. 2013. Results of a phase III clinical trial with an HBsAg-HBIG immunogenic complex therapeutic vaccine for chronic hepatitis B patients: Experiences and findings. J Hepatol 59: 450-456.

Yakut M, Seven G, Baran B, Kabaçam G, Bozkaya H, Karataylı E, Bozdayı M, Idılman R, Yurdaydın C. 2010. Clevudine treatment of chronic delta hepatitis. In EASL Monothematic Conference on Delta Hepatitis, Abstract Book, pp. 154. Istanbul, Turkey.

Yalçin K, Değertekin H, Yurdaydin C, Bozdayi M, Bozkaya H. 2003. The role of HBeAg seroconversion in acute exacerbation of liver disease with termination of hepatitis B and $\mathrm{D}$ virus infection in a chronic hepatitis $\mathrm{D}$ patient during $\alpha$ interferon therapy. Eur J Gastroenterol Hepatol 15: $819-823$.

Yan H, Zhong G, Xu G, He W, Jing Z, Gao Z, Huang Y, Qi Y, Peng B, Wang H, et al. 2012. Sodium taurocholate cotransporting polypeptide is a functional receptor for human hepatitis B and D virus. eLife 1: e00049.

Yilmaz E, Baran B, Soyer OM, Onel M, Onel D, Ormeci AC, Gokturk S, Evirgen S, Akyuz F, Demir K, et al. 2014. Effects of polymorphisms in interferon $\lambda 3$ (interleukin 28B) on sustained virologic response to therapy in patients with chronic hepatitis D virus infection. Clin Gastroenterol Hepatol 12: 1753-1758.

Yuen MF, Chan HLY, Given B, Hamilton J, Schuleup T, Lewis DL, Lai CL, Locarnini S, Lau JY, Gish RG. 2014. Phase II, dose ranging study of ARC-520, a siRNA-based therapeutic, in patients with chronic hepatitis B virus infection. Hepatology 60: LB-21.

Yurdaydin C. 2012. Treatment of chronic delta hepatitis. Semin Liver Dis 32: 237-244.

Yurdaydin C, Bozkaya H, Gürel S, Tillmann HL, Aslan N, Okçu-Heper A, Erden E, Yalçin K, Iliman N, Uzunalimoglu O, et al. 2002. Famciclovir treatment of chronic delta hepatitis. J Hepatol 37: 266-271.

Yurdaydin C, Bozkaya H, Karaaslan H, Onder FO, Erkan OE, Yalçin K, Değertekin H, Bozdayi AM, Uzunalimoğlu O. 2007. A pilot study of two years of interferon in patients with chronic delta hepatitis. J Viral Hepat 14: 812816.

Yurdaydin C, Bozkaya H, Onder FO, Sentürk H, Karaaslan H, Akdoğan M, Cetinkaya H, Erden E, Erkan-Esin O, Yalçin K, et al. 2008. Treatment of chronic delta hepatitis with lamivudine vs. lamivudine + interferon vs. interferon. J Viral Hepat 15: 314-321.

Yurdaydin C, Idilman R, Bozkaya H, Bozdayi AM. 2010. Natural history and treatment of chronic delta hepatitis. J Viral Hepat 17: 749-756.

Zachou K, Yurdaydin C, Drebber U, Dalekos GN, Erhardt A Cakaloglu Y, Degertekin H, Gurel S, Zeuzem S, Bozkaya H, et al. 2010. Quantitative HBsAg and HDV RNA levels in chronic delta hepatitis. Liver Int 30: 430-437.

Zavaglia C, Bottelli R, Smedile A, Iamoni G, Mondazzi L, Airoldi A, Lanzani F, Idéo G. 1996. A pilot study of thymosin- $\alpha 1$ therapy for chronic hepatitis D. J Clin Gastroenterol 23: 162-163.

Zhang E, Lu M. 2015. Toll like receptor (TLR)-mediated innate immune responses in the control of hepatitis B virus infection. Mol Microbiol Immunol 204: 11-20. 


\section{$\& \mathrm{CSH} \&$ Cold Spring Harbor

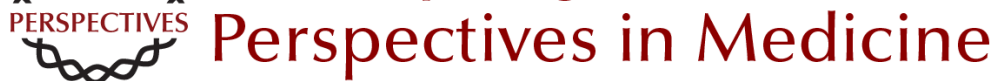

\section{Therapy of Delta Hepatitis}

Cihan Yurdaydin and Ramazan Idilman

Cold Spring Harb Perspect Med 2015; doi: 10.1101/cshperspect.a021543 originally published online August 7, 2015

Subject Collection The Hepatitis B and Delta Viruses

Hepatitis B Virus X and Regulation of Viral Gene Expression

Betty L. Slagle and Michael J. Bouchard

The Woodchuck, a Nonprimate Model for Immunopathogenesis and Therapeutic Immunomodulation in Chronic Hepatitis B Virus Infection

Michael Roggendorf, Anna D. Kosinska, Jia Liu, et al.

Mouse Models of Hepatitis B Virus Pathogenesis Matteo lannacone and Luca G. Guidotti

Therapy of Delta Hepatitis Cihan Yurdaydin and Ramazan Idilman

Immune Response in Hepatitis B Virus Infection Anthony Tan, Sarene Koh and Antonio Bertoletti

Hepatitis D Virus: Introduction and Epidemiology Mario Rizzetto

Management of Chronic Hepatitis B in Patients from Special Populations

Ching-Lung Lai and Man-Fung Yuen

Hepatitis B Virus Genotypes and Variants Chih-Lin Lin and Jia-Horng Kao
Origins and Evolution of Hepatitis B Virus and Hepatitis D Virus

Margaret Littlejohn, Stephen Locarnini and Lilly Yuen

Assembly and Release of Hepatitis B Virus Lisa Selzer and Adam Zlotnick

Hepatitis D Virus Replication John M. Taylor

Treatment of Liver Cancer Chun-Yu Liu, Kuen-Feng Chen and Pei-Jer Chen

Hepatitis B Virus and Hepatitis D Virus Entry, Species Specificity, and Tissue Tropism Koichi Watashi and Takaji Wakita

Hepadnavirus Genome Replication and

Persistence Jianming Hu and Christoph Seeger

The Chimpanzee Model for Hepatitis B Virus Infection

Stefan F. Wieland

Hepatitis B Virus Epidemiology

Jennifer H. MacLachlan and Benjamin C. Cowie

For additional articles in this collection, see http://perspectivesinmedicine.cshlp.org/cgi/collection/ 